\title{
In vitro and in vivo antileishmanial activity of $\beta$-acetyl-digitoxin, a cardenolide of Digitalis lanata potentially useful to treat visceral leishmaniasis
}

Camila S. Freitas ${ }^{1}$, Daniela P. Lage ${ }^{1}$, João A. Oliveira-da-Silva ${ }^{1}$, Rafaella R. Costa ${ }^{1}$, Débora V.C. Mendonçá ${ }^{1}$, Vívian T. Martins ${ }^{1}$, Thiago A.R. Reis ${ }^{1}$, Luciana M.R. Antinarelli ${ }^{2}$, Amanda S. Machado ${ }^{1}$, Grasiele S.V. Tavares ${ }^{1}$, Fernanda F. Ramos ${ }^{1}$, Rory C.F. Brito ${ }^{3}$, Fernanda Ludolf ${ }^{1}$, Miguel A. Chávez-Fumagalli ${ }^{4}$, Bruno M. Roatt ${ }^{3}$, Gabriela S. Ramos ${ }^{5}$, Jennifer Munkert ${ }^{6}$, Flaviano M. Ottoni ${ }^{5}$, Priscilla R.V. Campana ${ }^{5}$, Mariana C. Duarte ${ }^{1,7}$, Denise U. Gonçalves ${ }^{1}$, Elaine S. Coimbra ${ }^{2}$, Fernão C. Braga ${ }^{5}$, Rodrigo M. Pádua ${ }^{5}$, and Eduardo A.F. Coelho ${ }^{1,7, *}$

${ }^{1}$ Programa de Pós-Graduação em Ciências da Saúde: Infectologia e Medicina Tropical, Faculdade de Medicina, Universidade Federal de Minas Gerais, Belo Horizonte, 30130-100 Minas Gerais, Brazil

2 Departamento de Parasitologia, Microbiologia e Imunologia, Instituto de Ciências Biológicas, Universidade Federal de Juiz de Fora, Juiz de Fora, 36036-900 Minas Gerais, Brazil

${ }^{3}$ Laboratório de Imunopatologia, Núcleo de Pesquisas em Ciências Biológicas, Departamento de Ciências Biológicas, Insituto de Ciências Exatas e Biológicas, Universidade Federal de Ouro Preto, Ouro Preto, 35400-000 Minas Gerais, Brazil

${ }^{4}$ Universidad Católica de Santa María, Urb. San José S/N, Umacollo, 04000 Arequipa, Perú

5 Departamento de Produtos Farmacêuticos, Faculdade de Farmácia, Universidade Federal de Minas Gerais, Belo Horizonte, 31270-901 Minas Gerais, Brazil

${ }^{6}$ Departament Biologie, LS Pharmazeutische Biologie, Universität Erlangen-Nürnberg, 91054 Erlangen, Germany

7 Departamento de Patologia Clínica, COLTEC, Universidade Federal de Minas Gerais, Belo Horizonte, 31270-901 Minas Gerais, Brazil

Received 20 August 2020, Accepted 1 April 2021, Published online 14 April 2021

\begin{abstract}
Current treatments of visceral leishmaniasis face limitations due to drug side effects and/or high cost, along with the emergence of parasite resistance. Novel and low-cost antileishmanial agents are therefore required. We report herein the antileishmanial activity of $\beta$-acetyl-digitoxin (b-AD), a cardenolide isolated from Digitalis lanata leaves, assayed in vitro and in vivo against Leishmania infantum. Results showed direct action of b-AD against parasites, as well as efficacy for the treatment of Leishmania-infected macrophages. In vivo experiments using b-AD-containing Pluronic ${ }^{\circledR}$ F127 polymeric micelles (b-AD/Mic) to treat L. infantum-infected mice showed that this composition reduced the parasite load in distinct organs in more significant levels. It also induced the development of anti-parasite Th1-type immunity, attested by high levels of IFN- $\gamma$, IL-12, TNF- $\alpha$, GM-CSF, nitrite and specific IgG2a antibodies, in addition to low IL-4 and IL-10 contents, along with higher IFN- $\gamma$-producing CD4 ${ }^{+}$and CD8 ${ }^{+}$T-cell frequency. Furthermore, low toxicity was found in the organs of the treated animals. Comparing the therapeutic effect between the treatments, $\mathrm{b}-\mathrm{AD} / \mathrm{Mic}$ was the most effective in protecting animals against infection, when compared to the other groups including miltefosine used as a drug control. Data found 15 days after treatment were similar to those obtained one day post-therapy. In conclusion, the results obtained suggest that $b-A D / M i c$ is a promising antileishmanial agent and deserves further studies to investigate its potential to treat visceral leishmaniasis.
\end{abstract}

Key words: Treatment, $\beta$-acetyl-digitoxin, Visceral leishmaniasis, Drug repositioning, Toxicity, Miltefosine.

Résumé - Activité antileishmaniale in vitro et in vivo de la $\beta$-acétyl-digitoxine, un cardénolide de Digitalis lanata potentiellement utile pour traiter la leishmaniose viscérale. Les traitements actuels de la leishmaniose viscérale font face à des limitations dues aux effets secondaires des médicaments et/ou à leur coût élevé, ainsi qu'à l'émergence d'une résistance parasitaire. Des agents antileishmaniaux nouveaux et peu coûteux sont donc nécessaires. Nous rapportons ici l'activité antileishmaniale de la $\beta$-acétyl-digitoxine (b-AD), un cardénolide isolé à partir de feuilles de Digitalis lanata, mesurée in vitro et in vivo contre Leishmania infantum. Les résultats ont montré une action directe de la b-AD contre les parasites, ainsi qu'une efficacité pour le traitement des macrophages infectés par Leishmania. Des expériences in vivo utilisant des micelles polymériques Pluronic ${ }^{\circledR} \mathrm{F} 127$ contenant de la b-AD (b-AD/Mic) pour traiter des souris infectées par $L$. infantum ont montré que cette composition réduisait à des niveaux plus significatifs la charge parasitaire dans différents organes, ainsi que le développement d'une immunité antiparasitaire de type Th1, attestée par

*Corresponding author: eduardoferrazcoelho@yahoo.com.br 
les taux élevés d'IFN- $\gamma$, d'IL-12, de TNF- $\alpha$, de GM-CSF, de nitrite et d'anticorps IgG2a spécifiques, en plus des faibles taux d'IL-4 et IL-10, ainsi qu'une fréquence plus élevée des cellules T CD4 ${ }^{+}$and CD8 ${ }^{+}$productrices d' IFN- $\gamma$. De plus, une faible toxicité a été trouvée dans les organes des animaux traités. En comparant l'effet thérapeutique des traitements, b-AD/Mic était le plus efficace pour protéger les animaux contre l'infection, par rapport aux autres groupes comprenant la miltefosine utilisée comme contrôle médicamenteux. Les données trouvées 15 jours après le traitement étaient similaires à celles obtenues un jour après le traitement. En conclusion, les résultats obtenus suggèrent que b-AD/Mic est un agent antileishmanial prometteur et mérite des études supplémentaires pour étudier son potentiel à traiter la leishmaniose viscérale.

\section{Introduction}

Leishmaniases are vector-borne diseases caused by distinct species of protozoan parasites of the genus Leishmania. This disease complex is endemic in several countries in the world, where approximately 380 million people are at risk and 2.0 million new cases are registered per year [67]. Leishmaniases have distinct clinical manifestations, including tegumentary leishmaniasis (TL), which involves the cutaneous, mucosal and diffuse-cutaneous clinical forms, and visceral leishmaniasis (VL), which can be fatal if acute and untreated [33]. Disease control methods are not effective; the current treatment of human cases causes toxicity and/or has a high cost, in addition to the emergence of resistant parasite strains [62].

Visceral leishmaniasis is caused by Leishmania infantum in Latin America, Central Asia, and the Mediterranean region [3]. In symptomatic disease, splenomegaly, fever, anemia, weight loss, and weakness are commonly observed in the patients [66]. Ideally, a suitable treatment should be safe, non-toxic, and effective against parasites. Since the late 1940s, treatment is based on the use of pentavalent antimonials; however, these compounds are toxic, require intravenous or intramuscular administration, which is uncomfortable for the patients, and parasite resistance has increased [13, 49]. Amphotericin B (AmpB) has also been used as a treatment option. Although effective against Leishmania parasites, its toxicity is high. Lipid formulations have reduced AmpB toxicity and shown high efficacy; however, the high cost is still an impeditive factor [44]. Miltefosine has been also used as a therapeutic option in several countries, and it was the first oral drug administered against human VL. However, miltefosine causes teratogenicity and parasite resistance has been also registered [19]. Within this context, there is a need to research and develop novel and low-cost antileishmanial agents.

Drug discovery is a long and expensive process. In this regard, drug repositioning could be considered and tests using compounds with other known biological applications could be evaluated as antileishmanial agents $[4,6,10]$. Cardenolides are glycosides clinically used for over 200 years, with the mechanism of action based on the inhibition of $\mathrm{Na}^{+} / \mathrm{K}^{+}$ATPase, involved in the $\mathrm{Na}^{+} / \mathrm{K}^{+}$pump mechanism dependent on these ions $[8,41,46]$. Cardenolides have been used for the treatment of congestive heart failure [26], and present antitumor [56], anti-inflammatory [29], antimalarial [14], antioxidant, and anti-aging [68] activities.

The chemical investigation of Digitalis species resulted in the isolation of over 80 cardenolides, ascribed as the main bioactive constituents of the genus [21, 27]. Aiming to further explore new antileishmanial candidates, in the present work, the in vitro and in vivo activity of $\beta$-acetyl-digitoxin (b-AD) cardenolide, which was isolated from the leaves of $D$. lanata, was evaluated against $L$. infantum species. In vitro assays showed that $\mathrm{b}-\mathrm{AD}$ was effective against $L$. infantum promastigotes and amastigotes, and had low toxicity in murine and human cells. Preliminary data showed that this cardenolide derivative acts on parasite mitochondria, causing cell death. Additionally, in vivo treatment performed in $L$. infantum-infected mice showed that both free $\mathrm{b}-\mathrm{AD}$ and a composition formed by the molecule incorporated in polymeric micelles (b-AD/Mic) resulted in significant reductions in the parasite load in the spleen, liver, bone marrow (BM) and draining lymph nodes (dLN) of the animals, when analyses were performed 1 and 15 days post-treatment. Results obtained using miltefosine were similar to those found using the free molecule, but lower as compared to those found using b-AD/Mic. In addition, antiparasite Th1-type immunity was observed in the treated and infected animals, suggesting the possibility of testing this compound as a therapeutic target against VL.

\section{Materials and methods}

\section{Drugs and chemicals}

Miltefosine, AmpB, and Poloxamer 407 (Pluronic ${ }^{\circledR}$ F127) were commercially acquired and have catalog numbers 58066-85-6, 1397-89-3, and 16758, respectively (Sigma-Aldrich, St. Louis, MO, USA). $\beta$-acetyl-digitoxin $\left(\mathrm{C}_{43} \mathrm{H}_{66} \mathrm{O}_{14}\right.$; molecular weight $807 \mathrm{~g} / \mathrm{mol}$ ) was extracted and purified from leaves of Digitalis lanata species. After isolation and purification, the structural elucidation of the compound was carried out using ultraviolet spectrophotometry, mass spectrometry, and nuclear magnetic resonance. Data obtained were analyzed and the chemical structure was clarified (Fig. 1).

\section{Ethics statement, experimental animals, and parasites}

The work was submitted to and approved by the Ethics Committee in Animal Research (CEUA) from Federal University of Minas Gerais (UFMG; Belo Horizonte, Minas Gerais, Brazil), with protocol number 085/2017. Female BALB/c mice (6-8 weeks old) were acquired from the Institute of Biological Sciences (ICB) of UFMG and were kept under pathogen-free conditions. Leishmania infantum (MHOM/BR/1970/BH46) was grown in Schneider's medium (Sigma-Aldrich) added to $20 \%$ heat-inactivated fetal bovine serum (FBS; Sigma-Aldrich) and $20 \mathrm{mM}$ L-glutamine at $\mathrm{pH} 7.4,24^{\circ} \mathrm{C}$ [15]. 
<smiles>CC(=O)OC1C(O)CC(OC2C(O)CC(OC3C(O)CC(OC4CCC5(C)C(CCC6C5CCC5(C)C(C7=CC(=O)OC7)CCC65O)C4)OC3C)OC2C)OC1C</smiles>

Figure 1. Chemical structure of $\beta$-acetyl-digitoxin.

\section{In vitro antileishmanial activity}

The $50 \%$ Leishmania inhibitory concentration $\left(\mathrm{IC}_{50}\right)$ was evaluated in vitro by incubating logarithmic phase promastigotes in the presence of b-AD $(0-61.96 \mu \mathrm{M})$ or AmpB $(0-1.08 \mu \mathrm{M})$ in 96-well culture plates (Nunclon, Roskilde, Denmark) for $48 \mathrm{~h}$ at $24{ }^{\circ} \mathrm{C}$. Cell viability was assessed by the MTT [3-(4.5-dimethylthiazol-2-yl)-2.5-diphenyl tetrazolium bromide; Sigma-Aldrich] method. The optical density (OD) values were read in a microplate spectrophotometer (Spectra Max Plus, Molecular Devices, San Jose, CA, USA), at $570 \mathrm{~nm}$. Results were entered into Microsoft Excel (version 10.0) spreadsheets and $\mathrm{IC}_{50}$ values were calculated by sigmoidal regression of the dose-response curve [63].

\section{Cytotoxicity assay}

Cytotoxicity was evaluated in murine macrophages and human red blood cells, in which $50 \%$ inhibition of macrophages $\left(\mathrm{CC}_{50}\right)$ and red blood cells $\left(\mathrm{RBC}_{50}\right)$ was calculated. To do this, macrophages were obtained by peritoneal lavage of female BALB/c mice $(n=5)$ using $5 \mathrm{~mL}$ cold phosphate buffered saline (PBS $1 \times \mathrm{pH} 7.4)$. Peritoneal exudate cells were centrifuged at $1000 \times g$ for 10 min and resuspended in RPMI 1640 medium. Macrophages $\left(5 \times 10^{5}\right.$ cells $\left./ \mathrm{mL}\right)$ were then incubated with $(0-123.92 \mu \mathrm{M})$ or $\operatorname{AmpB}(0-10.82 \mu \mathrm{M})$ in RPMI 1640 medium for $48 \mathrm{~h}$ at $37^{\circ} \mathrm{C}$ in $5 \% \mathrm{CO}_{2}$. Cell viability was assayed by the MTT method. To evaluate hemolytic activity, a 5\% human red cell suspension was incubated with b-AD $(0-123.92 \mu \mathrm{M})$ or AmpB $(0-10.82 \mu \mathrm{M})$ for $1 \mathrm{~h}$ at $37^{\circ} \mathrm{C}$ in $5 \%$ $\mathrm{CO}_{2}$. The suspension was centrifuged at $1000 \times g$ for $10 \mathrm{~min}$ and the lysis percentage was read in a spectrophotometer, at $570 \mathrm{~nm}$. The absence or presence of hemolysis were evaluated by replacing b-AD for PBS or distilled water, respectively. Results were entered into Microsoft Excel spreadsheets and $\mathrm{CC}_{50}$ and $\mathrm{RBC}_{50}$ values were calculated using sigmoidal regression by means of dose-response curves [63].

\section{Treatment of infected macrophages and inhibition of infection}

Stationary phase promastigotes $\left(5 \times 10^{5}\right)$ were cultured in RPMI 1640 medium added to $20 \%$ FBS and $20 \mathrm{mM}$

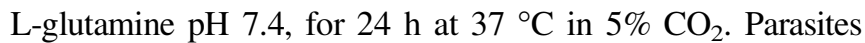
were then included in the cultures, at a ratio of 10 parasites per macrophage, and the incubation was developed for $48 \mathrm{~h}$ at $37{ }^{\circ} \mathrm{C}$ in $5 \% \mathrm{CO}_{2}$. Free parasites were removed by washing with medium and Leishmania-infected macrophages were incubated with b-AD $(0,3.09,6.19$ and $12.39 \mu \mathrm{M})$ or AmpB $(0,0.27,0.54$ and $1.08 \mu \mathrm{M})$ for $48 \mathrm{~h}$ at $24{ }^{\circ} \mathrm{C}$ in $5 \% \mathrm{CO}_{2}$. In another experiment, stationary phase promastigotes $\left(5 \times 10^{6}\right.$ cells $)$ were incubated with b-AD $(0,3.09,6.19$ and $12.39 \mu \mathrm{M})$ or $\operatorname{AmpB}(0,0.27,0.54$ and $1.08 \mu \mathrm{M})$ for $4 \mathrm{~h}$ at $24{ }^{\circ} \mathrm{C}$. Parasites were washed in RPMI 1640, quantified and added in culture to infect murine macrophages, at a ratio of 10 parasites per macrophage, for $48 \mathrm{~h}$ at $37^{\circ} \mathrm{C}$ in $5 \% \mathrm{CO}_{2}$. After cell fixation using $4 \%$ paraformaldehyde, cells were washed and stained with Giemsa, when the infection percentage, the number of amastigotes per treated macrophage, and the reduction in the infection percentage were determined by counting 200 cells, in triplicate, using an optical microscope [39].

\section{Evaluation of mitochondrial membrane potential}

Leishmania infantum promastigotes $\left(10^{7}\right.$ cells $)$ were cultured in the absence or presence of b-AD $(41.93 \mu \mathrm{M}$, corresponding to $2 \times$ the $\mathrm{IC}_{50}$ value) for $24 \mathrm{~h}$ at $25^{\circ} \mathrm{C}$. Parasites were washed in PBS and incubated with $500 \mathrm{nM}$ MitoTracker Red CM-H2XROS (Invitrogen, USA), for $30 \mathrm{~min}$ in the dark and at room temperature. After washing twice with PBS, cells were added to a black 96-well plate and fluorescence intensity was measured in a fluorometer $(\mathrm{FL} \times 800$, BioTek Instruments, Inc., Winooski, VT, USA), with excitation and emission wavelengths of $528 \mathrm{~nm}$ and $600 \mathrm{~nm}$, respectively. Parasites treated with carbonyl cyanide-4-(trifluoromethoxy)phenylhydrazone (FCCP; $5.0 \mu \mathrm{M}$ ) for $10 \mathrm{~min}$ were used as a positive control, while untreated parasites were used as a negative control [25].

\section{Reactive oxygen species (ROS) production}

Leishmania infantum promastigotes $\left(10^{7}\right.$ cells $)$ were cultured in the absence or presence of $\mathrm{b}-\mathrm{AD}(41.93 \mu \mathrm{M}$, corresponding to two times the $\mathrm{IC}_{50}$ value) for $24 \mathrm{~h}$ at $25^{\circ} \mathrm{C}$. After, parasites were incubated with $20 \mu \mathrm{M}$ cell-permeant $2^{\prime}, 7^{\prime}$ dichlorodihydrofluorescein diacetate $\left(\mathrm{H}_{2} \mathrm{DCFDA}\right.$; SigmaAldrich, USA) for $30 \mathrm{~min}$ in the dark and at room temperature. Fluorescence intensity was measured in a spectrofluorometer (Varioskan ${ }^{\circledR}$ Flash, Thermo Scientific, USA), with excitation and emission wavelengths of 485 and $528 \mathrm{~nm}$, respectively. $\mathrm{H}_{2} \mathrm{O}_{2}$-treated parasites (4000 $\mu \mathrm{M}$; Sigma-Aldrich, USA) were used as a positive control, while untreated parasites were used as a negative control [25]. 


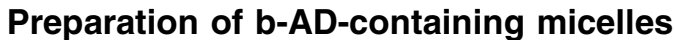

The b-AD-containing micelles (b-AD/Mic) were prepared as described elsewhere [54]. Briefly, Poloxamer 407 (18\% w/w) was diluted in PBS under magnetic agitation for $18 \mathrm{~h}$ at $4{ }^{\circ} \mathrm{C}$. Eight milligrams of b-AD were added to dichloromethane $(500 \mu \mathrm{L})$ and solubilized using a vortex. The mixture was added to the prepared solution under vigorous agitation and in ice bath, until a viscous emulsion was obtained. The alcohol was evaporated using a rotary evaporate (Buchi, Flawil, Switzerland), and the b-AD/Mic composition was obtained as a transparent yellow gel at $22{ }^{\circ} \mathrm{C}$. Empty micelles were prepared $(18 \% \mathrm{w} / \mathrm{w})$ using the protocol described above, but without addition of $\mathrm{b}-\mathrm{AD}$.

\section{Mice infection and treatment regimens}

Mice ( $n=12$ per group) were infected subcutaneously with L. infantum stationary-phase promastigotes $\left(10^{7}\right.$ parasites $)$ and, 60 days after, they were grouped and received one of the following regimens, which was administered by the subcutaneous route: saline group: mice received PBS $(50 \mu \mathrm{L})$; empty micelles (B/Mic) group: mice received empty micelles $(10 \mathrm{mg} / \mathrm{kg}$ body weight diluted in $50 \mu \mathrm{L}$ of PBS); miltefosine group: mice received miltefosine by oral route $(2 \mathrm{mg} / \mathrm{kg}$ body weight); b-AD group: mice received $\mathrm{b}-\mathrm{AD}$ ( $5 \mathrm{mg} / \mathrm{kg}$ body weight diluted in $50 \mu \mathrm{L}$ of $\mathrm{PBS}$ ), and b-AD/micelle (b-AD/Mic) group: mice received b-AD-containing micelles $(5 \mathrm{mg} / \mathrm{kg}$ body weight diluted in $50 \mu \mathrm{L}$ of PBS). Treatments were performed every two days and for 10 days. One and 15 days after treatment, half of the animals of each group were euthanized, when parasitological and immunological analyses were performed.

\section{Evaluation of parasite load}

Organ parasitism was evaluated in the spleen, liver, BM and $\mathrm{dLN}$ of the treated and infected animals, which were collected one and 15 days post-treatment, by a limiting dilution technique [64]. To this end, organs were macerated in a glass tissue grinder using sterile PBS, and tissue debris was removed by centrifugation at $150 \times g$. Cells were centrifuged at $2000 \times g$ and pellets were resuspended in $1 \mathrm{~mL}$ of complete Schneider's medium, when a log-fold serial dilution was performed in complete Schneider's medium. Each sample was plated in triplicate and read 7 days after the beginning of the cultures at $24{ }^{\circ} \mathrm{C}$. Results were expressed as the negative log of the titer (the dilution corresponding to the last positive well) adjusted per milligram of organ. Spleen parasitism was also evaluated by quantitative PCR (qPCR) [5, 20]. For this step, DNA was extracted using a commercial kit (Wizard Genomic DNA Purification Kit, Promega Corporation, Madison, WI, USA) and resuspended in milli-Q water. The following primers were used to amplify $L$. infantum kDNA: Forward (CCTATTTTA CACCAACCCCCAGT) and Reverse (GGGTAGGGGCGTT CTGCGAAA), while the $\beta$-actin gene (Forward: CAGAG CAAGAGAGGTATCC; Reverse: TCATTGTAGAAGGTGT GGTGC) was used as a control. Standard curves were obtained from DNA extracted from $10^{8}$ parasites for $\mathrm{kDNA}$ and $10^{8}$ macrophages for $\beta$-actin, using the same technical conditions. Reactions were performed and analyzed in an ABI Prism 7500 Sequence Detection System (96 wells-plate; Applied Biosystems), using $2 \times$ SYBR $^{\mathrm{TM}}$ Select Master Mix (Applied Biosystems), $2 \mathrm{mM}$ of each primer and $25 \mathrm{ng} / \mu \mathrm{L}$ DNA. Samples were incubated at $95{ }^{\circ} \mathrm{C}$ for $10 \mathrm{~min}$ and submitted to 40 cycles of $95{ }^{\circ} \mathrm{C}$ for $15 \mathrm{~s}$ and $60{ }^{\circ} \mathrm{C}$ for $1 \mathrm{~min}$. Fluorescence data were obtained at each time, and results were determined by interpolation from standard curves used in the same run, in duplicate, and expressed as the parasite number per total DNA.

\section{Cellular response}

Mice spleens were collected one and 15 days after treatment, when they $\left(5 \times 10^{6}\right.$ cells per $\left.\mathrm{mL}\right)$ were incubated in 24-well plates (Nunc) cultured in DMEM plus 20\% FBS and $20 \mathrm{mM}$ L-glutamine at $\mathrm{pH}$ 7.4. Cells were unstimulated (medium) or stimulated with $L$. infantum SLA $(50.0 \mu \mathrm{g} / \mathrm{mL})$ for $48 \mathrm{~h}$ at $37{ }^{\circ} \mathrm{C}$ in $5 \% \mathrm{CO}_{2}$. Levels of IFN- $\gamma$, IL-12, GM-CSF, IL-4, and IL-10 were measured in the culture supernatant by commercial kits obtained from BD Pharmingen ${ }^{\circledR}$ (San Diego, CA, USA), according to the manufacturer's instructions. Nitrite production was also evaluated in the cell supernatant by Griess reaction. In addition, in some culture wells, anti-CD4 (GK 1.5) and anti-CD8 (53-6.7) monoclonal antibodies (5.0 $\mu \mathrm{g}$ each; Pharmingen) were also added and processed as described above, aiming to evaluate the IFN- $\gamma$-producing T-cell profile in the miltefosine, $\mathrm{b}-\mathrm{AD}$ or $\mathrm{b}-\mathrm{AD} / \mathrm{Mic}$-treated mice groups. For this experiment, appropriate isotype-matched controls [rat IgG2a (R35-95) and rat IgG2b (95-1)] were also used. A flow cytometry assay was developed in the stimulated cultures to evaluate the IFN- $\gamma$ and IL-10-producing $\mathrm{CD}^{+}$and $\mathrm{CD}^{+} \mathrm{T}$ cell frequency. Experiments were based on the cell relative flow cytometry size (forward laser scatter - FSC) and granularity (side laser scatter - SSC) graphs. After selection of the interest region R1 containing FSCLow and SSCLow phenotype cells, graphs of density plot distribution of CD4/FL1 or CD8/FL1 versus IFN- $\gamma / \mathrm{FL}_{2}{ }^{+}, \mathrm{TNF}-\alpha / \mathrm{FL}^{+}{ }^{+}$and IL-10/FL2 ${ }^{+}$ cells were constructed to determine the IFN- $\gamma^{+}$, TNF- $\alpha$ and $\mathrm{IL}-10^{+}$-producing $\mathrm{T}$ cell frequency. Values were calculated by ratio between the $\mathrm{CD}^{+}$and $\mathrm{CD}^{+}$T-cell percentage in the SLA-stimulated versus unstimulated cultures, and they were expressed as indexes in the graphs [64].

\section{Antibody production}

Levels of anti-Leishmania IgG1 and IgG2a isotype antibodies were measured in serum samples of the treated animals, which were obtained one and 15 days after treatment, as described in [25]. Briefly, SLA was added as an antigen to the plates, at a concentration of $1.0 \mu \mathrm{g}$ per well, for $16 \mathrm{~h}$ at $4{ }^{\circ} \mathrm{C}$. Free binding sites were then blocked with PBS and Tween $200.05 \%$ (PBS-T) plus 5\% casein, for $1 \mathrm{~h}$ at $37{ }^{\circ} \mathrm{C}$, when plates were washed five times with PBS-T and incubated with mouse sera (1:100 diluted in PBS-T), for $1 \mathrm{~h}$ at $37{ }^{\circ} \mathrm{C}$. Afterwards, plates were washed five times and incubated with anti-mouse IgG1 and IgG2a horseradish-peroxidase conjugated antibodies (both 1:10,000 diluted in PBS-T), for $1 \mathrm{~h}$ at $37^{\circ} \mathrm{C}$. 
Table 1. In vitro biological assays. Leishmania infantum logarithmic phase promastigotes were incubated with b-AD $(0-61.96 \mu \mathrm{M})$ or AmpB $(0-1.08 \mu \mathrm{M})$ for $48 \mathrm{~h}$ at $24{ }^{\circ} \mathrm{C}$. Cell viability was analyzed by the MTT method and the $50 \%$ Leishmania inhibitory concentration (IC $\left.{ }_{50}\right)$ was calculated by applying sigmoidal regression of dose-response curve. Murine macrophages were also incubated with $\mathrm{b}-\mathrm{AD}(0-123.92 \mu \mathrm{M})$ or AmpB $(0-10.82 \mu \mathrm{M})$ for $48 \mathrm{~h}$ at $37{ }^{\circ} \mathrm{C}$ in $5 \% \mathrm{CO}_{2}$, and the $50 \%$ cell inhibitory concentration $\left(\mathrm{CC}_{50}\right)$ was also evaluated by a dose-response curve. The selectivity index (SI) was calculated by the ratio between the $\mathrm{CC}_{50}$ and $\mathrm{IC}_{50}$ values. The $50 \%$ human red blood cells inhibitory concentration $\left(\mathrm{RBC}_{50}\right)$ was determined by incubating the $5 \%$ red cell suspension with b-AD $(0-123.92 \mu \mathrm{M})$ or $\mathrm{AmpB}(0-10.82 \mu \mathrm{M})$ for $1 \mathrm{~h}$ at $37{ }^{\circ} \mathrm{C}$ in $5 \% \mathrm{CO}_{2}$. The lysis percentage was evaluated spectrophotometrically, and the absence or presence of hemolysis were determined by replacing b-AD for PBS or distilled water, respectively. Results are shown as mean \pm standard deviation of the groups.

\begin{tabular}{lcccc}
\hline Compound & $\mathrm{IC}_{50}(\mathrm{lM})$ & $\mathrm{CC}_{50}(\mathrm{lM})$ & $\mathrm{SI}$ & $\mathrm{RBC}(\mathrm{M})$ \\
\hline$\beta$-acetyl-digitoxin & $20.94 \pm 2.60$ & $453.04 \pm 23.29$ & 21.64 & $334.95 \pm 24.90$ \\
Amphotericin B & $0.11 \pm 0.03$ & $0.86 \pm 0.11$ & 7.82 & $12.66 \pm 1.52$ \\
\hline
\end{tabular}

Table 2. Evaluation of treatment of infected macrophages. Murine macrophages $\left(5 \times 10^{5}\right.$ cells) were cultured in complete RPMI 1640 medium for $24 \mathrm{~h}$ at $37{ }^{\circ} \mathrm{C}$ in $5 \% \mathrm{CO}_{2}$. After, cells were washed twice with PBS and L. infantum stationary promastigotes were added to the cultures at a ratio of 10 parasites per macrophage, for $48 \mathrm{~h}$ at $37{ }^{\circ} \mathrm{C}$ in $5 \% \mathrm{CO}_{2}$. Free parasites were removed by washing with RPMI 1640 medium, and infected macrophages were treated with b-AD $(0,3.09,6.19$ and $12.39 \mu \mathrm{M})$ or $\mathrm{AmpB}(0,0.27,0.54$ and $1.08 \mu \mathrm{M})$ for $48 \mathrm{~h}$ at $24{ }^{\circ} \mathrm{C}$ in $5 \% \mathrm{CO}_{2}$. The percentage of infected cells, the infectiveness reduction, and the number of recovered amastigotes per cell were determined by counting 200 macrophages in triplicate. Results are shown as mean \pm standard deviation of the groups.

\begin{tabular}{|c|c|c|c|c|}
\hline Compound & $\begin{array}{c}\text { Concentration } \\
(\mathrm{lM})\end{array}$ & $\begin{array}{c}\text { Percentage of infected } \\
\text { macrophages after treatment }\end{array}$ & $\begin{array}{l}\text { Infectiveness } \\
\text { reduction }(\%)\end{array}$ & $\begin{array}{c}\text { Number of amastigotes } \\
\text { per macrophage }\end{array}$ \\
\hline \multirow[t]{4}{*}{$\beta$-acetyl-digitoxin } & 12.39 & $7.6 \pm 1.2$ & 89.0 & $0.1 \pm 0$ \\
\hline & 6.19 & $14.3 \pm 2.5$ & 79.2 & $0.4 \pm 0.2$ \\
\hline & 3.09 & $24.3 \pm 3.3$ & 64.6 & $1.2 \pm 0.4$ \\
\hline & 0 & $68.7 \pm 4.0$ & $(-)$ & $3.9 \pm 0.5$ \\
\hline \multirow[t]{4}{*}{ Amphotericin B } & 1.08 & $19.8 \pm 2.4$ & 71.2 & $0.8 \pm 0.4$ \\
\hline & 0.54 & $32.1 \pm 3.8$ & 53.3 & $1.3 \pm 0.3$ \\
\hline & 0.27 & $42.5 \pm 5.2$ & 38.1 & $2.1 \pm 0.4$ \\
\hline & 0 & $68.7 \pm 4.0$ & $(-)$ & $3.9 \pm 0.5$ \\
\hline
\end{tabular}

Table 3. Inhibition of infection of macrophages. The inhibition of infection of murine macrophages using pre-treated parasites was performed by incubating $L$. infantum stationary promastigotes $\left(5 \times 10^{6}\right.$ cells) with b-AD $(0,3.09,6.19$ and $12.39 \mu \mathrm{M})$ or $\mathrm{AmpB}(0,0.27,0.54$ and $1.08 \mu \mathrm{M}$ ) for $4 \mathrm{~h}$ at $24^{\circ} \mathrm{C}$. Parasites were then washed in RPMI 1640 and used to infect murine cells at a ratio of 10 parasites per macrophage, for $48 \mathrm{~h}$ at $37{ }^{\circ} \mathrm{C}$ in $5 \% \mathrm{CO}_{2}$. The percentage of infected macrophages, the infectiveness reduction, and the number of amastigotes per treated macrophage were evaluated by counting 200 macrophages in triplicate. Results are shown as mean \pm standard deviation of the groups.

\begin{tabular}{lcccc}
\hline Compound & $\begin{array}{c}\text { Concentration } \\
(\mathrm{M})\end{array}$ & $\begin{array}{c}\text { Infection percentage using } \\
\text { pre-treated parasites }\end{array}$ & $\begin{array}{c}\text { Infectiveness } \\
\text { reduction (\%) }\end{array}$ & $\begin{array}{c}\text { Number of amastigotes } \\
\text { per macrophage }\end{array}$ \\
\hline$\beta$-acetyl-digitoxin & 12.39 & $8.8 \pm 2.0$ & 84.8 & $0.2 \pm 0.1$ \\
& 6.19 & $13.3 \pm 2.4$ & 77.0 & $0.7 \pm 0.3$ \\
& 3.09 & $27.4 \pm 4.0$ & 52.6 & $1.6 \pm 0.5$ \\
Amphotericin B & 0 & $57.8 \pm 5.2$ & $-)$ & $3.3 \pm 0.6$ \\
& 1.08 & $18.4 \pm 2.6$ & 54.2 & $0.7 \pm 0.3$ \\
& 0.54 & $26.5 \pm 2.7$ & 33.0 & $1.2 \pm 0.3$ \\
& 0.27 & $38.7 \pm 4.3$ & $(-)$ & $2.2 \pm 0.4$ \\
\hline
\end{tabular}

They were again washed and reactions were carried out using a solution composed of $\mathrm{H}_{2} \mathrm{O}_{2}$, ortho-phenylenediamine and citrate-phosphate buffer $\mathrm{pH}$ 5.0, for $30 \mathrm{~min}$ in the dark. Then, reactions were stopped by adding $2 \mathrm{~N} \mathrm{H}_{2} \mathrm{SO}_{4}$, and $\mathrm{OD}$ values were read in a spectrophotometer, at $492 \mathrm{~nm}$.

\section{In vivo toxicity}

In vivo cytotoxicity was evaluated in serum samples of the treated and infected animals, one and 15 days post-treatment.
For this evaluation, levels of aspartate aminotransferase (AST), alanine aminotransferase (ALT), and creatine kinase muscle brain fraction (CK-MB) were determined in the samples, using commercial kits (Labtest Diagnostica ${ }^{\circledR}$, Belo Horizonte, Brazil) according to the manufacturer's instructions.

\section{Statistical analysis}

$\mathrm{IC}_{50}, \mathrm{CC}_{50}$ and $\mathrm{RBC}_{50}$ values were entered into Microsoft Excel (version 10.0) spreadsheets and calculated by 
dose-response curves, which were plotted in GraphPad Prism 5.03. Results were evaluated by the one-way analysis of variance (ANOVA), followed by Bonferroni's post-test. Data were expressed as mean \pm standard deviation of the groups. Two independent experiments presenting similar results were performed and differences were considered significant when $p<0.05$.

\section{Results}

\section{In vitro biological assays}

The in vitro antileishmanial effect of the compounds was evaluated against $L$. infantum species, where $\mathrm{IC}_{50}$ values of $20.94 \pm 2.60$ and $0.11 \pm 0.03 \mu \mathrm{M}$ were obtained for $\mathrm{b}-\mathrm{AD}$ and $\mathrm{AmpB}$, respectively (Table 1). In turn, $\mathrm{CC}_{50}$ and $\mathrm{RBC}_{50}$ values determined for $\mathrm{b}$-AD were $453.04 \pm 23.29$ and $334.95 \pm 24.90 \mu \mathrm{M}$, respectively, and $0.86 \pm 0.11$ and $12.66 \pm 1.52 \mu \mathrm{M}$ for AmpB, respectively. The calculated selectivity indexes were 21.64 and 7.82 for $\mathrm{b}-\mathrm{AD}$ and $\mathrm{AmpB}$, respectively (Table 1). Treatment of infected macrophages reduced the infection percentage by $89.0 \%$ and $71.2 \%$, when b-AD and AmpB were tested at 12.39 and $1.08 \mu \mathrm{M}$, respectively (Table 2). The inhibition of infection using pre-treated parasites was also evaluated, and results showed reductions in the infection percentage by $84.8 \%$ and $68.2 \%$, when b-AD and $\mathrm{AmpB}$ were assayed at 12.39 and $1.08 \mu \mathrm{M}$, respectively (Table 3). Preliminary investigations of the effects of b-AD in L. infantum suggested that the compound caused alterations in parasite mitochondria, by altering their membrane potential (Fig. 2) and causing an increase in ROS production (Fig. 3).

\section{Estimation of the parasite load}

Organ parasitism was evaluated one and 15 days posttreatment in liver, spleen, BM and dLNs of the treated animals. Results showed that the miltefosine, free $\mathrm{b}-\mathrm{AD}$ or $\mathrm{b}-\mathrm{AD} / \mathrm{Mic}$ group mice presented significant reductions in the parasite load as compared to values encountered in the saline and B/Mic groups (Fig. 4). One day post-therapy, miltefosine, b-AD and $\mathrm{b}-\mathrm{AD} / \mathrm{Mic}$ group mice presented lower parasitism in their spleens (3.0, 3.7 and 4.6-log reductions, respectively), livers (2.3, 2.7 and 4.0-log reductions, respectively), dLNs (3.7, 4.3 and 5.3-log reductions, respectively), and BMs (1.7, 2.0 and 2.7-log reductions, respectively), when compared to the saline group. Fifteen days after treatment, reductions in the parasite load in the miltefosine, $\mathrm{b}-\mathrm{AD}$ and $\mathrm{b}-\mathrm{AD} / \mathrm{Mic}$ groups were in the order of 3.3, 4.0 and 5.7-log reductions, respectively, in their spleens; of 2.7, 3.0 and 4.3-log reductions, respectively, in their livers; of 4.0, 4.7 and 6.0-log reductions, respectively, in their dLNs; and of 2.0, 2.3 and 3.7-log reductions, respectively, in their BM; when compared to the saline group. Comparison between the treated groups revealed that mice receiving $\mathrm{b}-\mathrm{AD} / \mathrm{Mic}$ showed the highest reductions in organ parasitism. The spleens of the animals were also used to determine the parasite load by qPCR technique, and results also showed that miltefosine, free $\mathrm{b}-\mathrm{AD}$ or $\mathrm{b}-\mathrm{AD} /$ Mic-treated mice

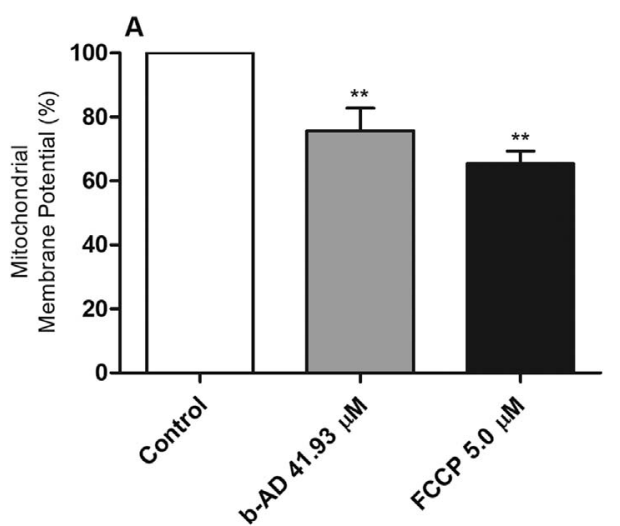

Figure 2. Evaluation of mitochondrial membrane potential. Leishmania infantum $\left(10^{7}\right.$ cells) were incubated alone (control) or in the presence of b-AD $\left(41.93 \mu \mathrm{M}\right.$, corresponding to two times the $\mathrm{IC}_{50}$ value) for $24 \mathrm{~h}$ at $25{ }^{\circ} \mathrm{C}$. Parasites were then incubated with MitoTracker Red CM-H2XROS for $30 \mathrm{~min}$ and in the dark. Cells were washed twice with PBS and transferred to a black 96-well plate, when the fluorescence intensity was evaluated using a fluorometer. Promastigotes treated with carbonyl cyanide-4-(trifluoromethoxy)phenylhydrazone (FCCP; $5.0 \mu \mathrm{M}$ ) were used as a positive control, while those untreated were used as a negative control (control). Bars represent the mean plus standard deviation of the groups. (**) indicates a statistically significant difference as compared to the control $(p<0.0001)$.

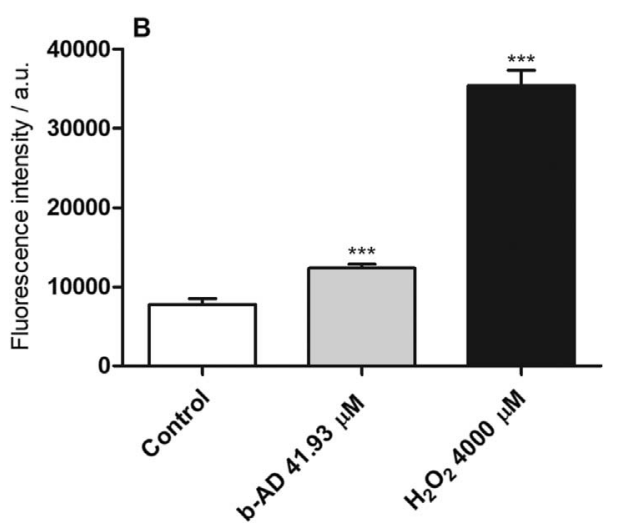

Figure 3. Production of reactive oxygen species. Leishmania infantum $\left(10^{7}\right.$ cells) were incubated alone (control) or in the presence of b-AD $(41.93 \mu \mathrm{M})$ for $24 \mathrm{~h}$ at $25^{\circ} \mathrm{C}$. Parasites were then washed twice in PBS and incubated with $20 \mu \mathrm{M}$ cell-permeant $2^{\prime}, 7^{\prime}$ dichlorodihydrofluorescein diacetate $\left(\mathrm{H}_{2}\right.$ DCFDA) for $30 \mathrm{~min}$ and in the dark. Fluorescence was measured in a fluorometer, with excitation and emission wavelengths of 485 and $528 \mathrm{~nm}$, respectively. $\mathrm{H}_{2} \mathrm{O}_{2}(4000 \mu \mathrm{M}$; Sigma-Aldrich, USA)-treated parasites were used as a positive control, while untreated parasites were used as a negative control (control). Bars represent the mean plus standard deviation of the groups. $(* * *)$ indicates a statistically significant difference as compared to the control $(p<0.0001)$.

presented significant reductions in splenic parasitism, when compared to values found in the control groups. Additionally, $\mathrm{b}-\mathrm{AD} / \mathrm{Mic}$ also induced the highest reductions in splenic parasitism as compared to the others (Fig. 5). 


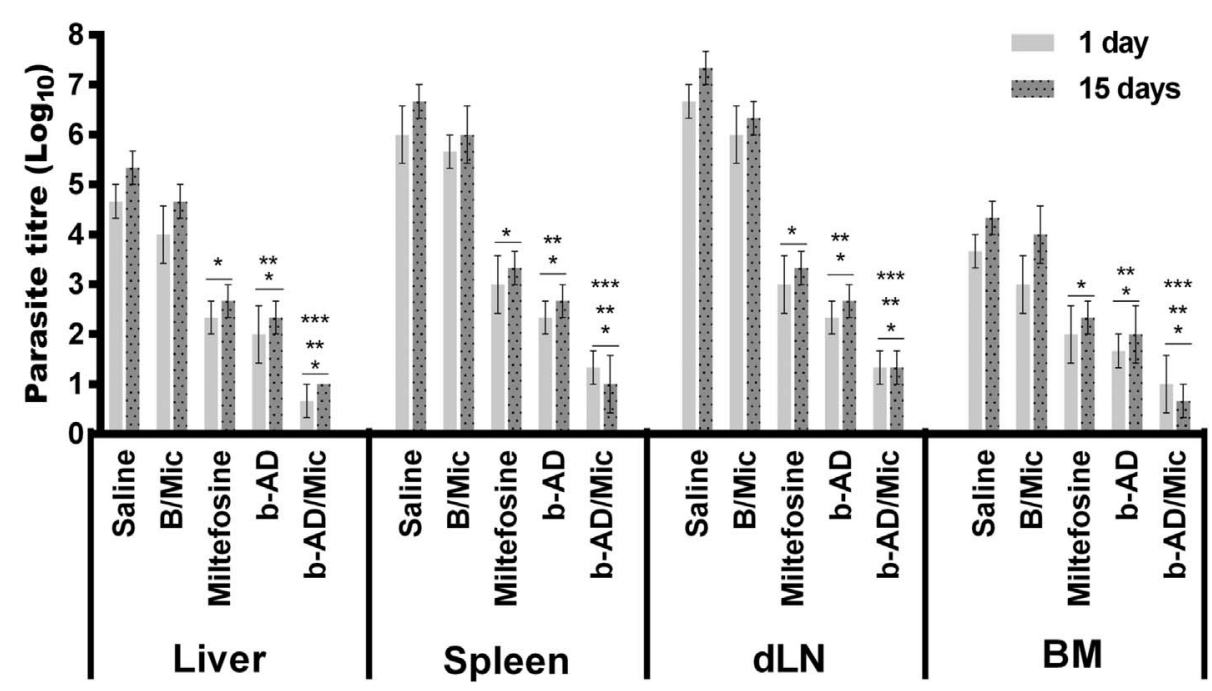

Figure 4. Organ parasitism evaluated in the treated animals by a limiting dilution technique. Mice $(n=12$ per group) were infected with L. infantum and, 1 and 15 days after the distinct treatment schedules, they ( $n=6$ per group in each time) were euthanized and their livers, spleens, bone marrow (BM) and draining lymph nodes (dLNs) were collected to evaluate the parasite load, by a limiting dilution technique. Bars represent the mean \pm standard deviation of the groups. $(*)$ indicates a significant difference as compared to the saline and B/Mic groups $(p<0.05)$. $(* *)$ indicates a statistically significant difference as compared to the miltefosine group $(p<0.05)$. (***) indicates a statistically significant difference as compared to the $\mathrm{b}-\mathrm{AD}$ group $(p<0.05)$.

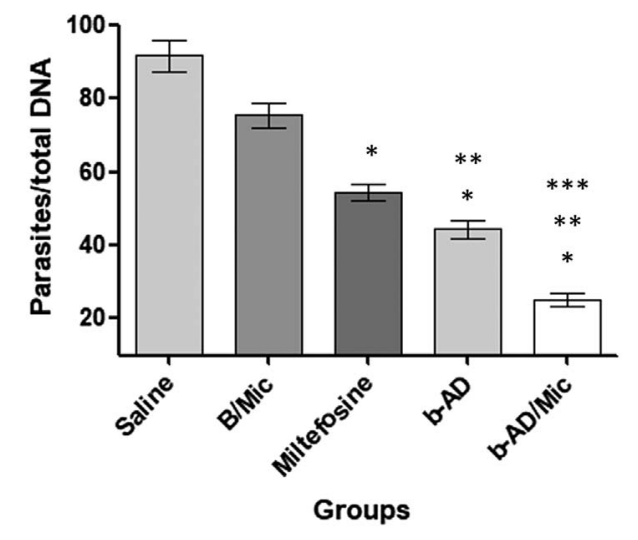

Figure 5. Splenic parasitism estimated by quantitative PCR. Leishmania infantum-infected mice $(n=6$ per group) were submitted to the distinct treatment regimens and, 15 days post-therapy, they were euthanized and their spleens were collected to evaluate parasitism by qPCR. Results were expressed as the number of parasites per total DNA, and bars represent the mean \pm standard deviation of the groups. $\left(^{*}\right)$ indicates a significant difference as compared to the saline and $\mathrm{B} / \mathrm{Mic}$ groups $(p<0.05)$. $(* *)$ indicates a statistically significant difference as compared to the miltefosine group $(p<0.05)$. $(* * *)$ indicates a statistically significant difference as compared to the $\mathrm{b}-\mathrm{AD}$ group $(p<0.05)$.

\section{Immune response in the treated animals}

Anti-parasite Th1 and Th2-type cytokines were evaluated in the cell supernatant of splenocyte cultures of the treated animals. Results showed that spleen cells of miltefosine, b-AD or b-AD/Mic groups mice produced significantly higher levels of IFN- $\gamma$, IL-12 and GM-CSF, as well as low levels of IL-4 and IL-10, when compared to data found in the saline and $\mathrm{B} / \mathrm{Mic}$ groups, when both periods of time were evaluated
(Fig. 6). Aiming to investigate the T cell subtype responsible by IFN- $\gamma$ production in the treated and infected animals, antiCD4 and anti-CD8 monoclonal antibodies were added to the in vitro cultures, and results showed that both antibody subtypes reduced production of this cytokine in significant levels. This suggests that $\mathrm{CD}^{+}$and $\mathrm{CD}^{+} \mathrm{T}$ cells were important for immunological response against $L$. infantum infection (Fig. 7). A flow cytometry assay also showed that miltefosine, b-AD and b-AD/Mic-treated mice presented higher IFN- $\gamma$ and TNF- $\alpha$-producing T-cell subtype frequency as compared to data obtained in the saline and $\mathrm{B} / \mathrm{Mic}$ groups, which showed higher IL-10-producing $\mathrm{CD}^{+}$and $\mathrm{CD}^{+}$T-cell levels (Fig. 8). Between the therapeutics, b-AD/Mic induced higher presence of IFN- $\gamma$ and TNF- $\alpha$-producing $\mathrm{CD}^{+}$and $\mathrm{CD} 8^{+} \mathrm{T}$ cells. Nitrite production was evaluated by Griess reaction, and results showed that miltefosine, $b-\mathrm{AD}$ or $\mathrm{b}-\mathrm{AD} / \mathrm{Mic}$ group mice produced higher levels of this cell activation marker, when compared to values found in the saline and B/Mic groups (Fig. 9). The evaluation of humoral response also showed that miltefosine, b-AD or b-AD/Mic group mice produced significantly higher levels of anti-Leishmania IgG2a antibody, as compared to IgG1 levels. Otherwise, saline and B/Mic group mice produced higher anti-parasite IgG1 isotype levels than IgG2a isotype, in both periods of time post-treatment (Fig. 10). The treatment using b-AD/Mic induced the highest levels of anti-parasite $\operatorname{IgG} 2 \mathrm{a}$ antibodies as compared to the other groups.

\section{In vivo toxicity}

Hepatic and cardiac toxicity was evaluated in the treated and infected animals. Results showed higher levels of ALT, AST and CK-MB enzymes in the saline and B/Mic group mice, suggesting that organic changes could occur in these animals 

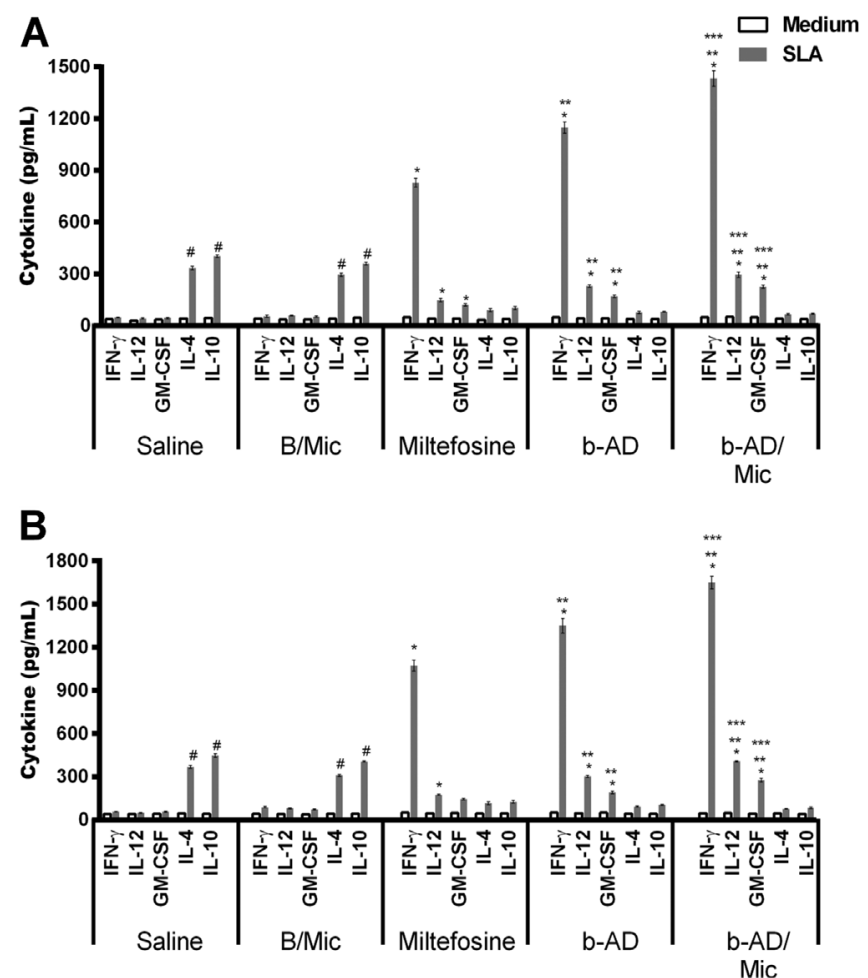

Figure 6. Cellular response generated in the treated animals. $\mathrm{BALB} / \mathrm{c}$ mice ( $n=12$ per group) were infected with $L$. infantum promastigotes and submitted to distinct treatment schedules. 1 and 15 days post-therapy, they were euthanized and their spleens were collected and splenocytes were unstimulated (medium) or stimulated with L. infantum SLA $(50.0 \mu \mathrm{g} / \mathrm{mL})$, for $48 \mathrm{~h}$ at $37{ }^{\circ} \mathrm{C}$ in $5 \% \mathrm{CO}_{2}$. Levels of IFN- $\gamma$, IL-4, IL-10, IL-12 and GM-CSF were quantified in the cell supernatant, one (A) and 15 (B) days post-treatment, by capture ELISA. Bars represent the mean \pm standard deviation of the groups. $(*)$ indicates a significant difference as compared to the saline and B/Mic groups $(p<0.05)$. $(* *)$ indicates a statistically significant difference as compared to the miltefosine group $(p<0.05)$. $(* * *)$ indicates a statistically significant difference as compared to the b-AD group $(p<0.05)$. (\#) indicates a statistically significant difference as compared to the miltefosine, b-AD and b-AD/Mic groups $(p<0.05)$.

caused by infection and/or treatment. On the other hand, the miltefosine, $b-A D$ and $b-A D / M i c$ group mice produced lower levels of these enzymatic markers, with animals treated with $\mathrm{b}-\mathrm{AD} / \mathrm{Mic}$ being those presenting the lowest levels of AST, ALT and CK-MB (Fig. 11).

\section{Discussion}

Drugs currently used for VL treatment are toxic, costly, have long treatment times to achieve a therapeutic effect and/or variable efficacy [61]. In this context, novel antileishmanial agents are needed and plant products may represent a valid strategy for drug development [53], especially compounds or derivatives in clinical use, such as cardenolide derivatives. Cardiac glycosides such as digoxin are used to heart diseases, and several compounds of this class have been described to induce a plethora of biological responses, including anti-inflammatory

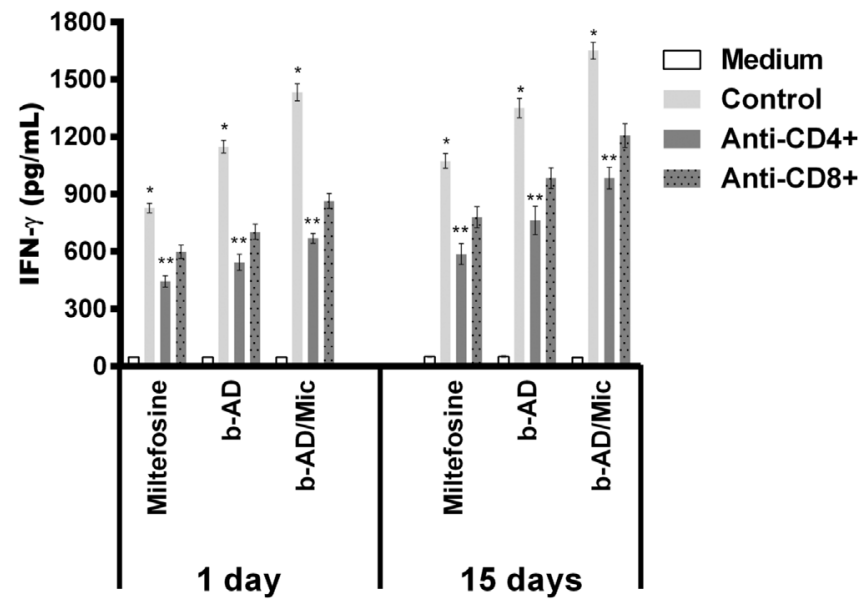

Figure 7. T-cell subtypes involved in the IFN- $\gamma$ production. Splenocytes of mice treated with miltefosine, b-AD or b-AD/Mic ( $n=6$ per group) were cultured in DMEM (medium) or stimulated with SLA $(50.0 \mu \mathrm{g} / \mathrm{mL})$ in the presence of anti-CD4 or anti-CD8 antibody, for $48 \mathrm{~h}$ at $37{ }^{\circ} \mathrm{C}$ in $5 \% \mathrm{CO}_{2}$. IFN- $\gamma$ levels were quantified in the cell supernatant by a capture ELISA. Bars represent the mean \pm standard deviation of the groups. (*) indicates a statistically significant difference as compared to the use of anti-CD4 or antiCD8 antibody $(p<0.05)$. (**) indicates a statistically significant difference as compared to the use of anti-CD8 antibody $(p<0.05)$.

and antiprotozoal activities [14, 29, 68]. Following the rationale to identify novel antileishmanial targets, in the present work, a cardenolide derivative called $\beta$-acetyl-digitoxin, which was obtained from Digitalis lanata leaves, was evaluated regarding its in vitro and in vivo activity against $L$. infantum. The obtained results indicated the effectiveness of $\mathrm{b}-\mathrm{AD}$ against the parasites, especially when it was tested incorporated in Poloxamer 407-based polymeric micelles. This composition was more efficient in reducing the parasite load in the treated and infected animals, and also in inducing a more polarized and specific antileishmanial Th1-type response.

The occurrence of active VL depends on the activation of T cell subsets, being Th1-type cytokines, such as IFN- $\gamma$, GM-CSF and IL-12, among others related to the protective response, while IL-4, IL-5, IL-6, IL-10, among others related to the development of the disease [16, 18, 31, 42]. Usually, protective immunity depends on the induction of specific Th1-type response, which activates macrophages to kill intracellular parasites through nitric oxide-mediated mechanism [30]. In this study, considering the analysis of T-cell populations and cytokine production, both $\mathrm{CD}^{+}$and $\mathrm{CD}^{+} \mathrm{T}$ subtypes were shown to be the origin of IFN- $\gamma$ in mice that were treated with miltefosine, b-AD or b-AD/Mic. The Th1-type profile was related to parasitism control in distinct organs of the animals, when the parasite load was evaluated through a limiting dilution technique and $\mathrm{qPCR}$. On the other hand, control group mice showed higher parasitism in these systemic organs, as well as the development of Th2-type immune response. Parasitological and immunological evaluations performed 1 and 15 days posttreatment indicated the maintenance of the positive therapeutic response in the treated animals, suggesting possible long-term efficacy of b-AD against $L$. infantum. 


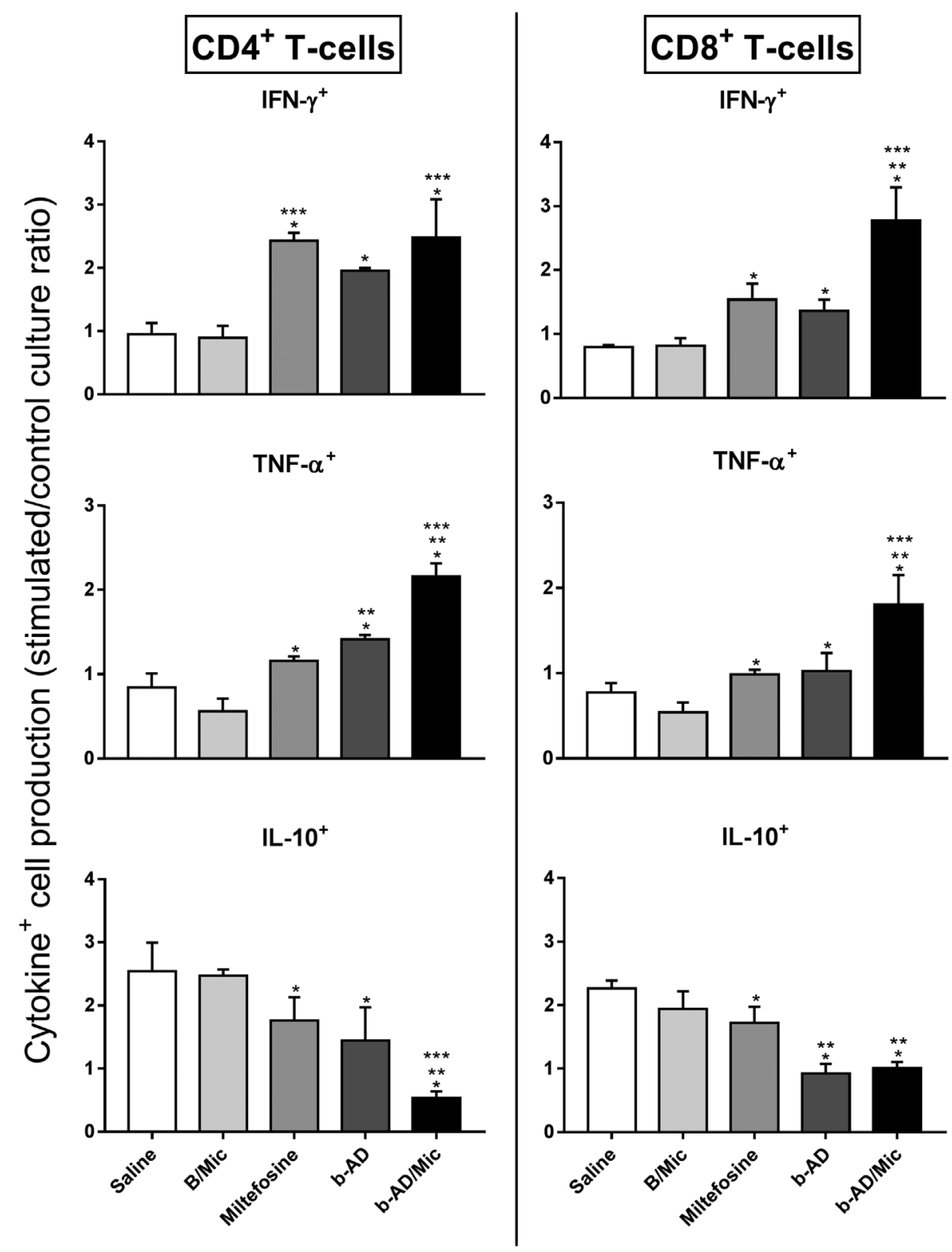

Figure 8. Investigation of intracytoplasmic cytokine-producing $\mathrm{T}$ cell frequency. Cytometry flow was performed to evaluate the IFN- $\gamma$, TNF- $\alpha$ and IL-10-producing T CD4 ${ }^{+}$and $\mathrm{CD}^{+}$cell frequency in splenocytes of mice treated, 15 days post-therapy. Results were calculated by the ratio between SLA-stimulated versus unstimulated cultures (SLA/CC ratio), and reported as cytokine indexes for CD $4^{+}$and $\mathrm{CD} 8^{+} \mathrm{T}$ cells. Bars represent the mean plus standard deviation of the groups. $\left(^{*}\right)$ indicates a significant difference as compared to the saline and B/Mic groups $(p<0.05)$. $(* *)$ indicates a statistically significant difference as compared to the miltefosine group $(p<0.05)$. (***) indicates a statistically significant difference as compared to the $\mathrm{b}-\mathrm{AD}$ group $(p<0.05)$.

In our study, b-AD showed higher therapeutic efficacy when it was incorporated in Poloxamer 407 (Pluronic ${ }^{\circledR}$ F127)-based polymeric micelles. The use of micelles as delivery vehicles for antileishmanial molecules has presented good therapeutic efficacy against Leishmania spp. [20, 34, 37]. In one study, AmpB-containing polymeric micelles were tested against $L$. donovani, and results showed that the composition was 100 times more active against parasites as compared to the use of free AmpB [23]. In another study, AmpB-containing and chitosan-coated Poloxamer 407-based micelles were prepared and the composition was tested against Leishmania, with results showing low toxicity of formulation in mammalian cells, higher uptake by host macrophages and higher efficacy against infection by the parasites [54].

Our group also used polymeric micelles as delivery systems for antileishmanial candidates. In a study, AmpB-containing Poloxamer P407 micelles were prepared and tested against L. amazonensis. Results showed that the composition induced significant reductions in the parasite load in infected BALB/c mice, as compared to the other groups. Th1-type immunity developed in these treated animals, which was associated with the therapeutic response against infection [37]. In another study, clioquinol-containing Pluronic $^{\circledR}$ F127 polymeric micelles (ICHQ/Mic) were developed and tested against L. amazonensis. 


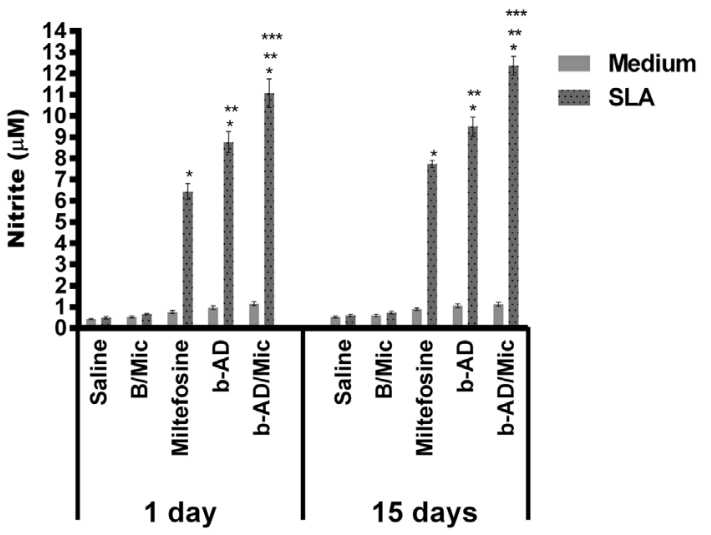

Figure 9. Nitrite production evaluated by Griess reaction. The cellular supernatants used to quantify cytokines in both periods of time after treatments were also used to evaluate SLA-specific nitrite production. Bars represent the mean \pm standard deviation of the groups. (*) indicates a significant difference as compared to the saline and $\mathrm{B} / \mathrm{Mic}$ groups $(p<0.05)$. (**) indicates a statistically significant difference as compared to the miltefosine group $(p<0.05)$. $(* * *)$ indicates a statistically significant difference as compared to the b-AD group $(p<0.05)$. (\#) indicates a statistically significant difference as compared to the miltefosine, $\mathrm{b}-\mathrm{AD}$ and b-AD/Mic groups $(p<0.05)$.

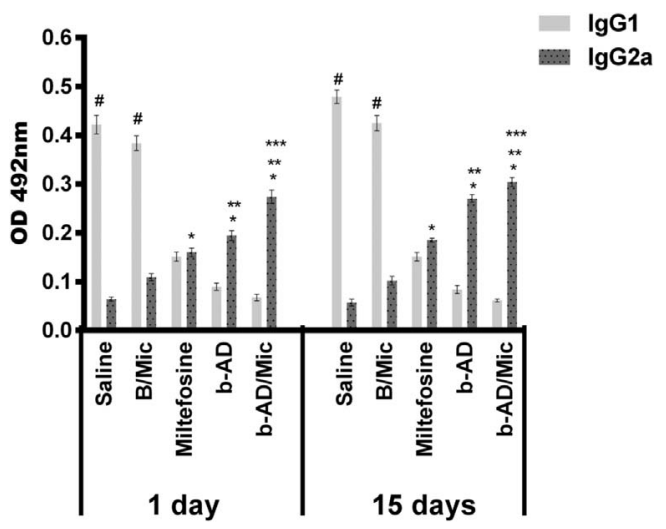

Figure 10. Antibody response produced in the treated animals. Serum samples were collected of mice infected and later treated, 1 and 15 days post-therapy, and levels of anti-parasite IgG1 and IgG2a isotypes were investigated by ELISA. Bars represent the mean \pm standard deviation of the groups. $(*)$ indicates a significant difference as compared to the saline and $\mathrm{B} / \mathrm{Mic}$ groups $(p<0.05)$. $(* *)$ indicates a statistically significant difference as compared to the miltefosine group $(p<0.05)$. (***) indicates a statistically significant difference as compared to the b-AD group $(p<0.05)$. (\#) indicates a statistically significant difference as compared to the miltefosine, b-AD and b-AD/Mic groups $(p<0.05)$.

Results showed that treated mice developed a Th1-type immune response, which was associated with significant reductions in parasitism in livers, spleens, BMs and dLNs of the animals, when compared to data found in the control groups [64].

Cardenolides have been used to treat congestive heart failure and arrhythmias [1, 11, 32, 52]. In the present study, preliminary data suggest that the mechanism of action of our cardenolide derivative in $L$. infantum involved the parasite mitochondria causing cell death, since b-AD altered mitochondrial membrane potential and stimulated ROS production by the parasites. In fact, the presence of high levels of ROS can cause increased levels of lipid peroxidation and reduction in membrane fluidity, leading to the loss of cell viability [55, 58]. Mitochondria have been considered a target when distinct antileishmanial agents were tested [7, 28, 35, 57, 63]; however, contrarily to what was observed in mammalian cells, where this organelle is abundant in their content, Leishmania spp. and other trypanosomatids present only one mitochondrion, which exhibits functional and morphological differences, such as the presence of its own genetic material, peculiarities in the functionality of the electron transport chain, and existence of non-canonical antioxidant machinery [2, 24, 40]. In this context, and based on the data presented here, b-AD was able to induce a stress environment in the parasites, which contributed to Leishmania death. Additionally, and due to the low toxicity found in murine and human cells, one could speculate that this compound will not be toxic to treat human VL, mainly when administered at low doses and/or incorporated in delivery systems such as polymeric micelles.

Miltefosine is used as an oral drug for the treatment against VL; however, its effectiveness has been variable between different populations $[51,60]$. In addition, due to its long half-life and long treatment duration, parasite resistance against this drug has also been documented [45, 47]. Here, miltefosine induced significant reductions in parasitism in the treated animals, as compared to values found in the controls; however, data obtained in b-AD/Mic-treated mice, showing more significant reductions in the parasite load, suggest that the micellar composition was more effective in reducing organ parasitism in treated and infected animals. Taken together, these results suggest that b-AD/Mic could be considered effective against $L$. infantum infection in our experimental mammalian model.

Infection by $L$. infantum usually causes primary parasitism in the liver of the animals that tends to decrease, while splenic parasitism tends to increase when the infection becomes chronic $[12,43]$. In this context, animal spleens could be considered a marker of chronic infection $[22,36]$. In our study, parasitism in this organ was evaluated by two distinct techniques and results showed that when both assays were performed, lower splenic parasitism was found in $\mathrm{b}-\mathrm{AD} / \mathrm{Mic}$-treated mice, as compared to the other groups, including the treatment using miltefosine. This fact could be considered relevant and therapeutic schemes testing the association of this cardenolide derivative with other antileishmanial drugs could be considered. The purpose would be to reduce the side effects, decrease parasite resistance, and allow the prescription of lower drug doses to achieve satisfactory therapeutic results $[30,48,59,65]$.

Limitations of the study include the absence of other therapeutic schedules employing lower numbers of doses and other antileishmanial agents, such as amphotericin B, as well as the absence of parasitological and immunological evaluations performed over longer periods of time post-treatment, aiming to verify possible long-term therapeutic efficacy induced by $\mathrm{b}-\mathrm{AD} / \mathrm{Mic}$. In addition, the absence of evaluation of levels of urea and creatinine in the serum samples of treated and infected animals could be considered a limitation of the work, since antileishmanial agents, such as amphotericin B [38, 50], 


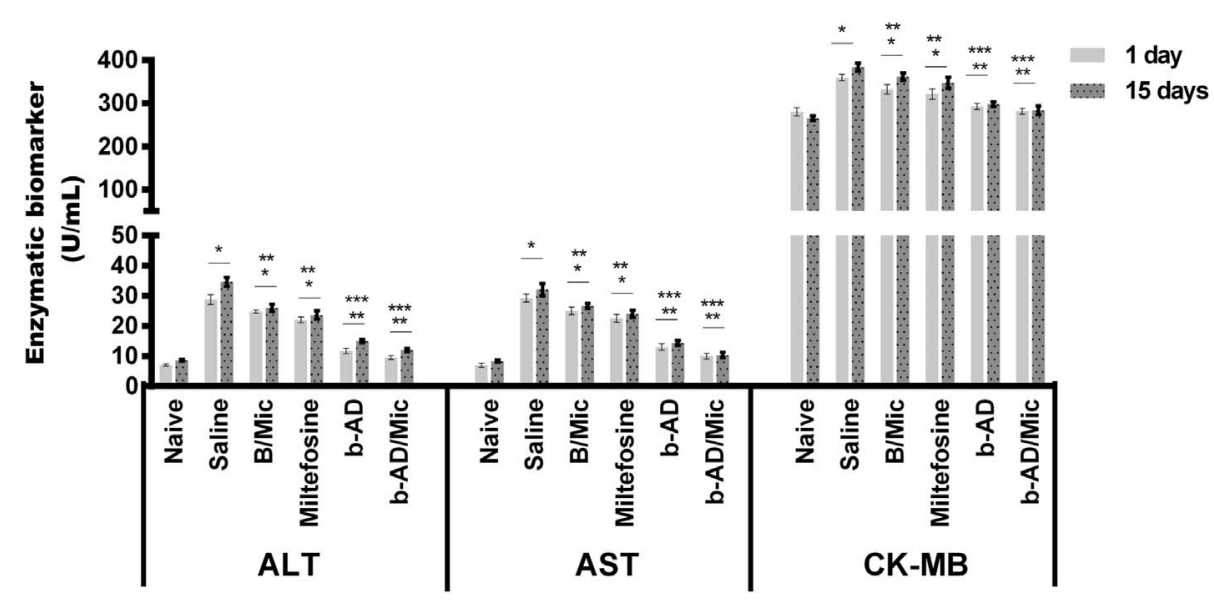

Figure 11. In vivo cytotoxicity. To investigate the in vivo toxicity of the therapeutics, levels of alanine aminotransferase (ALT), aspartate aminotransferase (AST), and creatine kinase muscle brain fraction (CK-MB) enzymes were quantified in serum samples of mice infected and treated, 1 and 15 days post-therapy. Samples of naive (non-infected and non-treated) mice were used as control. Bars represent the mean \pm standard deviation of the groups. $(*)$ indicates a significant difference as compared to the saline and $\mathrm{B} / \mathrm{Mic}$ groups $(p<0.05)$. $(* *)$ indicates a statistically significant difference as compared to the miltefosine group $(p<0.05)$. (***) indicates a statistically significant difference as compared to the $\mathrm{b}-\mathrm{AD}$ group $(p<0.05)$. (\#) indicates a statistically significant difference as compared to the miltefosine, $\mathrm{b}-\mathrm{AD}$ and $\mathrm{b}-\mathrm{AD} / \mathrm{Mic}$ groups $(p<0.05)$.

cardenolide derivatives [9, 17], among others, can cause renal toxicity, mainly if administered in high and/or inappropriately doses [9]. In this context, additional studies are needed, aiming to solve such questions. However, preliminary data presented here, describing the parasitological and immunological therapeutic response found in mice treated with $\mathrm{b}-\mathrm{AD} / \mathrm{Mic}$, as well as the low cardiac and hepatic toxicity, suggest that this compound could be considered in future studies as a therapeutic agent against VL.

\section{Conflict of interest}

The authors confirm that they have no conflicts of interest in relation to this work.

Acknowledgements. This work was supported by grant MR/ R005850/1 from the Medical Research Council (VAccine deveLopment for complex Intracellular neglecteD pAThogEns - VALIDATE), UK, and grant APQ-408675/2018-7 from the Conselho Nacional de Desenvolvimento Científico e Tecnológico (CNPq), Brazil. The authors also thank the Brazilian agencies Coordenação de Aperfeiçoamento de Pessoal de Nível Superior (CAPES), CNPq and the Fundação de Amparo à Pesquisa do Estado de Minas Gerais (FAPEMIG) for the student scholarships. The authors would also like to thank Professor Wolfgang Kreis (Universität Erlangen-Nürnberg - Germany) for kindly providing a sample of $\beta$-acetyldigitoxin.

\section{References}

1. Akbari M, Oryan A, Hatam G. 2017. Application of nanotechnology in treatment of leishmaniasis: a review. Acta Tropica, 172, 86-90.

2. Alonso-Garrido M, Manyes L, Pralea IE, Iuga CA. 2020. Mitochondrial proteomics profile points oxidative phosphorylation as main target for beauvericin and enniatin B mixture. Food and Chemical Toxicology, 141, 111432.
3. Alvar J, Vélez ID, Bern C, Herrero M, Desjeux P, Cano J, Jannin J, den Boer M, WHO Leishmaniasis Control Team. 2012. Leishmaniasis worldwide and global estimates of its incidence. PLoS One, 7, e35671.

4. Andrade-Neto VV, Cunha-Junior EF, Santos Faioes V, Pereira TM, Silva RL, Leon LL, Torres-Santos EC. 2018. Leishmaniasis treatment: update of possibilities for drug repurposing. Frontiers in Bioscience, 23, 967-996.

5. Antonia AL, Wang L, Ko DC. 2018. A real-time PCR assay for quantification of parasite burden in murine models of leishmaniasis. PeerJ, 6, e5905.

6. Araújo IAC, Paula RC, Alves CL, Faria KF, Oliveira MM, Mendes GG, Dias EMFA, Ribeiro RR, Oliveira AB, Silva SMD. 2019. Efficacy of lapachol on treatment of cutaneous and visceral leishmaniasis. Experimental Parasitology, 199, 67-73.

7. Arruda CCP, Hardoim DJ, Rizk YS, Souza CSF, Valle TZ, Carvalho DB, Taniwaki NN, Baroni ACM, Calabrese KS. 2019. A triazole hybrid of neolignans as a potential antileishmanial agent by triggering mitochondrial dysfunction. Molecules, 25, 37.

8. Askari A. 2019. The sodium pump and digitalis drugs: dogmas and fallacies. Pharmacology Research \& Perspectives, 7, $\mathrm{e} 00505$.

9. Bauman JL, Didomenico RJ, Galanter WL. 2006. Mechanisms, manifestations, and management of digoxin toxicity in the modern era. American Journal of Cardiovascular Drugs, 6, 77-86.

10. Braga SS. 2019. Multi-target drugs active against leishmaniasis: a paradigm of drug repurposing. European Journal of Medicinal Chemistry, 183, 111660.

11. Campbell TJ, MacDonald PS. 2003. Digoxin in heart failure and cardiac arrhythmias. Medical Journal of Australia, 179, 98-102.

12. Carrión J, Nieto A, Iborra S, Iniesta V, Soto M, Folgueira C, Abanades DR, Requena JM, Alonso C. 2006. Immunohistological features of visceral leishmaniasis in BALB/c mice. Parasite Immunology, 28, 173-183.

13. Chakravarty J, Sundar S. 2019. Current and emerging medications for the treatment of leishmaniasis. Expert Opinion on Pharmacotherapy, 20, 1251-1265.

14. Chan EW, Wong SK, Chan HT. 2016. Apocynaceae species with antiproliferative and/or antiplasmodial properties: a review of ten genera. Journal of Integrative Medicine, 14, 269-284. 
15. Coelho EAF, Tavares CA, Carvalho FA, Chaves KF, Teixeira KN, Rodrigues RC, Charest H, Matlashewski G, Gazzinelli RT, Fernandes AP. 2003. Immune responses induced by the Leishmania (Leishmania) donovani A2 antigen, but not by the LACK antigen, are protective against experimental Leishmania (Leishmania) amazonensis infection. Infection and Immunity, 71, 3988-3994.

16. Cortes S, Bruno-de-Sousa C, Morais T, Lago J, Campino L. 2020. Potential of the natural products against leishmaniasis in Old World: a review of in vitro studies. Pathogens and Global Health, 27, 1-13.

17. Critchley JA, Critchley LA. 1997. Digoxin toxicity in chronic renal failure: treatment by multiple dose activated charcoal intestinal dialysis. Human \& Experimental Toxicology, 16, 733-735.

18. Dayakar A, Chandrasekaran S, Kuchipudi SV, Kalangi SK. 2019. Cytokines: key determinants of resistance or disease progression in visceral leishmaniasis: opportunities for novel diagnostics and immunotherapy. Frontiers in Immunology, 10, 670.

19. Dorlo TP, Balasegaram M, Beijnen JH, Vries PJ. 2012. Miltefosine: a review of its pharmacology and therapeutic efficacy in the treatment of leishmaniasis. Journal of Antimicrobial Chemotherapy, 67, 2576-2597.

20. Duarte MC, Lage LM, Lage DP, Martins VT, Carvalho AM, Roatt BM, Menezes-Souza D, Tavares CA, Alves RJ, Barichello JM, Coelho EA. 2016. Treatment of murine visceral leishmaniasis using an 8-hydroxyquinoline-containing polymeric micelle system. Parasitology International, 65, 728-736.

21. Eid SY, El-Readi MZ, Wink M. 2012. Digitonin synergistically enhances the cytotoxicity of plant secondary metabolites in cancer cells. Phytomedicine, 19, 1307-1314.

22. Engwerda CR, Kaye PM. 2000. Organ-specific immune responses associated with infectious disease. Immunology Today, 21, 73-78.

23. Espuelas S, Legrand P, Loiseau PM, Bories C, Barratt G, Irache JM. 2000. In vitro reversion of amphotericin B resistance in Leishmania donovani by Poloxamer 188. Antimicrobial and Agents Chemotherapy, 44, 2190-2192.

24. Fidalgo LM, Gille L. 2011. Mitochondria and trypanosomatids: targets and drugs. Pharmaceutical Research, 28, 2758-2770.

25. Freitas CS, Oliveira-da-Silva JA, Lage DP, Costa RR, Mendonça DVC, Martins VT, Reis TAR, Antinarelli LMR, Machado AS, Tavares GSV, Ramos FF, Coelho VTS, Brito RCF, Ludolf F, Chávez-Fumagalli MA, Roatt BM, Ramos GS, Munkert J, Ottoni FM, Campana PRV, Humbert MV, Coimbra ES, Braga FC, Pádua RM, Coelho EAF. 2021. Digitoxigenin presents an effective and selective antileishmanial action against Leishmania infantum and is a potential therapeutic agent for visceral leishmaniasis. Parasitology Research, 120, 321-335.

26. Gheorghiade M, Harinstein ME, Filippatos GS. 2009. Digoxin for the treatment of chronic and acute heart failure syndromes. Acute Cardiac Care, 11, 83-87.

27. Gurel E, Karvar S, Yucesan B, Eker I, Sameeullah M. 2017. An overview of cardenolides in digitalis - more than a cardiotonic compound. Current Pharmaceutical Design, 23, 5104-5114.

28. Granato JT, Santos JA, Calixto SL, Prado da Silva N, da Silva Martins J, Silva AD, Coimbra ES. 2018. Novel steroid derivatives: synthesis, antileishmanial activity, mechanism of action, and in silico physicochemical and pharmacokinetics studies. Biomedicine \& Pharmacotherapy, 106, 1082-1090.

29. Jagielska J, Salguero G, Schieffer B, Bavendiek U. 2009. Digitoxin elicits anti-inflammatory and vasoprotective properties in endothelial cells: therapeutic implications for the treatment of atherosclerosis? Atherosclerosis, 206, 390-396.

30. Joshi J, Kaur S. 2014. Studies on the protective efficacy of second-generation vaccine along with standard antileishmanial drug in Leishmania donovani infected BALB/c mice. Parasitology, 141, 554-562.

31. Kedzierski L, Evans KJ. 2014. Immune responses during cutaneous and visceral leishmaniasis. Parasitology, 30, 1-19.

32. Keenan SM, DeLisle RK, Welsh WJ, Paula S, Ball WJ Jr. 2005. Elucidation of the $\mathrm{Na}^{+}, \mathrm{K}^{+}$-ATPase digitalis binding site. Journal of Molecular Graphics and Modelling, 23, 465-475.

33. Kevric I, Cappel MA, Keeling JH. 2015. New World and Old World Leishmania infections: a practical review. Dermatologic Clinics, 33, 579-593.

34. Lage LM, Barichello JM, Lage DP, Mendonça DV, Carvalho AM, Rodrigues MR, Menezes-Souza D, Roatt BM, Alves RJ, Tavares CA, Coelho EA, Duarte MC. 2016. An 8-hydroxyquinoline-containing polymeric micelle system is effective for the treatment of murine tegumentary leishmaniasis. Parasitology Research, 115, 4083-4095.

35. López-Arencibia A, Martín-Navarro C, Sifaoui I, Reyes-Batlle M, Wagner C, Lorenzo-Morales J, Maciver SK, Piñero JE. 2017. Perifosine mechanisms of action in Leishmania species. Antimicrobial Agents and Chemotherapy, 61, e02127-16.

36. Melby PC, Yang YZ, Cheng J, Zhao W. 1998. Regional differences in the cellular immune response to experimental cutaneous or visceral infection with Leishmania donovani. Infection and Immunity, 66, 18-27.

37. Mendonça DVC, Lage LMR, Lage DP, Chávez-Fumagalli MA, Ludolf F, Roatt BM, Menezes-Souza D, Faraco AA, Castilho RO, Tavares CA, Barichello JM, Duarte MC, Coelho EA. 2016. Poloxamer 407 (Pluronic ${ }^{\circledR}$ F127)-based polymeric micelles for amphotericin B: in vitro biological activity, toxicity and in vivo therapeutic efficacy against murine tegumentary leishmaniasis. Experimental Parasitology, 169, 34-42.

38. Mendonça DVC, Martins VT, Lage DP, Dias DS, Ribeiro PAF, Carvalho AMRS, Dias ALT, Miyazaki CK, Menezes-Souza D, Roatt BM, Tavares CAP, Barichello JM, Duarte MC, Coelho EAF. 2018. Comparing the therapeutic efficacy of different amphotericin B-carrying delivery systems against visceral leishmaniasis. Experimental Parasitology, 186, 24-35.

39. Mendonça DVC, Tavares GSV, Lage DP, Soyer TG, Carvalho LM, Dias DS, Ribeiro PAF, Ottoni FM, Antinarelli LMR, Vale DL, Ludolf F, Duarte MC, Coimbra ES, Chávez-Fumagalli MA, Roatt BM, Menezes-Souza D, Barichello JM, Alves RJ, Coelho EAF. 2019. In vivo antileishmanial efficacy of a naphthoquinone derivate incorporated into a Pluronic $^{\circledR}$ F127-based polymeric micelle system against Leishmania amazonensis infection. Biomedicine \& Pharmacotherapy, 109, 779-787.

40. Menna-Barreto RF, Castro SL. 2014. The double-edged sword in pathogenic trypanosomatids: the pivotal role of mitochondria in oxidative stress and bioenergetics. Biomed Research International, 2014, 614014.

41. Mijatovic T, Kiss R. 2013. Cardiotonic steroids-mediated $\mathrm{Na}^{+} / \mathrm{K}^{+}$-ATPase targeting could circumvent various chemoresistance pathways. Planta Medica, 79, 189-198.

42. Mougneau E, Bihl F, Glaichenhaus N. 2011. Cell biology and immunology of Leishmania. Immunology Review, 240, 286-296.

43. Oliveira DM, Costa MA, Chavez-Fumagalli MA, Valadares DG, Duarte MC, Costa LE, Martins VT, Gomes RF, Melo MN, Soto M, Tavares CA, Coelho EA. 2012. Evaluation of parasitological and immunological parameters of Leishmania chagasi infection in BALB/c mice using different doses and routes of inoculation of parasites. Parasitology Research, 110, 1277-1285.

44. Ortega V, Giorgio S, Paula E. 2017. Liposomal formulations in the pharmacological treatment of leishmaniasis: a review. Journal of Liposome Research, 27, 234-248. 
45. Pandey K, Ravidas V, Siddiqui NA, Sinha SK, Verma RB, Singh TP, Dhariwal AC, Das Gupta RK, Das P. 2016. Pharmacovigilance of miltefosine in treatment of visceral leishmaniasis in endemic areas of Bihar, India. American Journal of Tropical Medicine and Hygiene, 95, 1100-1105.

46. Patel CN, Kumar SP, Modi KM, Soni MN, Modi NR, Pandya HA. 2019. Cardiotonic steroids as potential $\mathrm{Na}(+) / \mathrm{K}(+)$-ATPase inhibitors - a computational study. Journal of Receptors and Signal Transduction, 39, 226-234.

47. Pérez-Victoria FJ, Sánchez-Cañete MP, Seifert K, Croft SL, Sundar S, Castanys S, Gamarro F. 2006. Mechanisms of experimental resistance of Leishmania to miltefosine: implications for clinical use. Drug Resistance Updates, 9, 26-39.

48. Perron GG, Kryazhimskiy S, Rice DP, Buckling A. 2012. Multidrug therapy and evolution of antibiotic resistance: when order matters. Applied and Environmental Microbiology, 78, 6137-6142.

49. Ponte-Sucre A, Gamarro F, Dujardin JC, Barrett MP, LópezVélez R, García-Hernández R, Pountain AW, Mwenechanya R, Papadopoulou B. 2017. Drug resistance and treatment failure in leishmaniasis: a 21st century challenge. PLoS Neglected Tropical Diseases, 11, e0006052.

50. Ribeiro TG, Franca JR, Fuscaldi LL, Santos ML, Duarte MC, Lage PS, Martins VT, Costa LE, Fernandes SO, Cardoso VN, Castilho RO, Soto M, Tavares CA, Faraco AA, Coelho EA, Chávez-Fumagalli MA. 2014. An optimized nanoparticle delivery system based on chitosan and chondroitin sulfate molecules reduces the toxicity of amphotericin B and is effective in treating tegumentary leishmaniasis. International Journal of Nanomedicine, 9, 5341-5353.

51. Rijal S, Ostyn B, Uranw S, Rai K, Bhattarai NR, Dorlo TP, Beijnen JH, Vanaerschot M, Decuypere S, Dhakal SS, Das ML, Karki P, Singh R, Boelaert M, Dujardin JC. 2013. Increasing failure of miltefosine in the treatment of Kala-azar in Nepal and the potential role of parasite drug resistance, reinfection, or noncompliance. Clinical Infectious Diseases, 56, 1530-1538.

52. Scalese MJ, Salvatore DJ. 2017. Role of digoxin in atrial fibrillation. Journal of Pharmacy Practice, 30, 434-440.

53. Sen R, Chatterjee M. 2011. Plant derived therapeutics for the treatment of leishmaniasis. Phytomedicine, 18, 1056-1069.

54. Singh PK, Pawar VK, Jaiswal AK, Singh Y, Srikanth CH, Chaurasia M, Bora HK, Raval K, Meher JG, Gayen JR, Dube A, Chourasia MK. 2017. Chitosan coated Pluronic F127 micelles for effective delivery of amphotericin B in experimental visceral leishmaniasis. International Journal of Biological Macromolecules, 105, 1220-1231.

55. Slimen IB, Najar T, Ghram A, Dabbebi H, Ben Mrad M, Abdrabbah M. 2014. Reactive oxygen species, heat stress and oxidative-induced mitochondrial damage. A review. International Journal of Hyperthermia, 30, 513-523.

56. Slingerland $M$, Cerella $C$, Guchelaar HJ, Diederich $M$, Gelderblom H. 2013. Cardiac glycosides in cancer therapy: from preclinical investigations towards clinical trials. Investigational New Drugs, 31, 1087-1094.
57. Sousa JKT, Antinarelli LMR, Mendonça DVC, Lage DP, Tavares GSV, Dias DS, Ribeiro PAF, Ludolf F, Coelho VTS, Oliveira-da-Silva JA, Perin L, Oliveira BA, Alvarenga DF, Chávez-Fumagalli MA, Brandão GC, Nobre V, Pereira GR, Coimbra ES, Coelho EAF. 2019. A chloroquinoline derivate presents effective in vitro and in vivo antileishmanial activity against Leishmania species that cause tegumentary and visceral leishmaniasis. Parasitology International, 73, 101966.

58. Su LJ, Zhang JH, Gomez H, Murugan R, Hong X, Xu D, Jiang F, Peng ZY. 2019. Reactive oxygen species-induced lipid peroxidation in apoptosis, autophagy, and ferroptosis. Oxidative Medicine and Cellular Longevity, 2019, 5080843.

59. Sun W, Zhang H, Guo J, Zhang X, Zhang L, Li C, Zhang L. 2016. Comparison of the efficacy and safety of different ace inhibitors in patients with chronic heart failure: a PRISMAcompliant network meta-analysis. Medicine (Baltimore), 95, e2554.

60. Sundar S, Singh A, Rai M, Prajapati VK, Singh AK, Ostyn B, Boelaert M, Dujardin JC, Chakravarty J. 2012. Efficacy of miltefosine in the treatment of visceral leishmaniasis in India after a decade of use. Clinical Infectious Diseases, 55, 543-550.

61. Sundar S, Singh A. 2016. Recent developments and future prospects in the treatment of visceral leishmaniasis. Therapeutic Advances in Infectious Disease, 3, 98-109.

62. Sundar S, Singh A. 2018. Chemotherapeutics of visceral leishmaniasis: present and future developments. Parasitology, 145, 481-489.

63. Tavares GSV, Mendonça DVC, Lage DP, Granato JDT, Ottoni FM, Ludolf F, Chávez-Fumagalli MA, Duarte MC, Tavares CAP, Alves RJ, Coimbra ES, Coelho EAF. 2018. Antileishmanial activity, cytotoxicity and mechanism of action of clioquinol against Leishmania infantum and Leishmania amazonensis species. Basic \& Clinical Pharmacology \& Toxicology, 123, 236-246.

64. Tavares GSV, Mendonça DVC, Pereira IAG, Oliveira-da-Silva JA, Ramos FF, Lage DP, Machado AS, Carvalho LM, Reis TAR, Perin L, Carvalho AMRS, Ottoni FM, Ludolf F, Freitas CS, Bandeira RS, Silva AM, Chávez-Fumagalli MA, Duarte MC, Menezes-Souza D, Alves RJ, Roatt BM, Coelho EAF. 2020. A clioquinol-containing Pluronic ${ }^{\circledR}$ F127 polymeric micelle system is effective in the treatment of visceral leishmaniasis in a murine model. Parasite, 27, 29.

65. Trinconi CT, Reimão JQ, Yokoyama-Yasunaka JK, Miguel DC, Uliana SR. 2014. Combination therapy with tamoxifen and amphotericin B in experimental cutaneous leishmaniasis. Antimicrobial Agents and Chemotherapy, 58, 2608-2613.

66. Uliana SRB, Trinconi CT, Coelho AC. 2018. Chemotherapy of leishmaniasis: present challenges. Parasitology, 145, 464-480.

67. World Health Organization. 2018. Leishmaniasis. http://www. who.int/topics/leishmaniasis/en/. Accessed data: 2 June 2018.

68. Xu J, Guo Y, Sui T, Wang Q, Zhang Y, Zhang R, Wang M, Guan S, Wang L. 2017. Molecular mechanisms of anti-oxidant and anti-aging effects induced by convallatoxin in Caenorhabditis elegans. Free Radical Research, 51, 529-544.

Cite this article as: Freitas CS, Lage DP, Oliveira-da-Silva JA, Costa RR, Mendonça DVC, Martins VT, Reis TAR, Antinarelli LMR, Machado AS, Tavares GS, Ramos FF, Brito RCF, Ludolf F, Chávez-Fumagalli MA, Roatt BM, Ramos GS, Munkert J, Ottoni FM, Campana PRV, Duarte MC, Gonçalves DU, Coimbra ES, Braga FC, Pádua RM \& Coelho EAF. 2021. In vitro and in vivo antileishmanial activity of $\beta$-acetyl-digitoxin, a cardenolide of Digitalis lanata potentially useful to treat visceral leishmaniasis. Parasite $\mathbf{2 8}, 38$. 
An international open-access, peer-reviewed, online journal publishing high quality papers on all aspects of human and animal parasitology

Reviews, articles and short notes may be submitted. Fields include, but are not limited to: general, medical and veterinary parasitology; morphology, including ultrastructure; parasite systematics, including entomology, acarology, helminthology and protistology, and molecular analyses; molecular biology and biochemistry; immunology of parasitic diseases; host-parasite relationships; ecology and life history of parasites; epidemiology; therapeutics; new diagnostic tools.

All papers in Parasite are published in English. Manuscripts should have a broad interest and must not have been published or submitted elsewhere. No limit is imposed on the length of manuscripts.

Parasite (open-access) continues Parasite (print and online editions, 1994-2012) and Annales de Parasitologie Humaine et Comparée (1923-1993) and is the official journal of the Société Française de Parasitologie. 